\title{
Channel adjustments and island dynamics in the Brenta River (Italy) over the last $\mathbf{3 0}$ years
}

\begin{tabular}{|r|l|}
\hline Journal: & River Research and Applications \\
\hline Manuscript ID: & RRA-12-0053.R2 \\
\hline Wiley - Manuscript type: & Research Article \\
\hline Date Submitted by the Author: & O2-May-2013 \\
\hline Complete List of Authors: & $\begin{array}{l}\text { Moretto, Johnny; University of Padova, Department of Land, Environment, } \\
\text { Agriculture and Forestry } \\
\text { Rigon, Emanuel; University of Padova, Department of Land, Environment, } \\
\text { Agriculture and Forestry } \\
\text { Mao, Luca; Universidad Católica de Chile, Department of Ecosystems and } \\
\text { Environment } \\
\text { Picco, Lorenzo; University of Padova, Department of Land, Environment, } \\
\text { Agriculture and Forestry } \\
\text { Delai, Fabio; University of Padova, Department of Land, Environment, } \\
\text { Agriculture and Forestry } \\
\text { Lenzi, Mario; University of Padova, Department of Land, Environment, } \\
\text { Agriculture and Forestry }\end{array}$ \\
\hline Keywords: & \begin{tabular}{l} 
Planform changes, Islands dynamics, Human impact, Floods, Brenta River \\
\hline
\end{tabular} \\
\hline
\end{tabular}

\section{SCHOLARONE ${ }^{\text {m }}$}

Manuscripts 
1 Channel adjustments and island dynamics in the Brenta River

2 (Italy) over the last 30 years

3

\author{
J. Moretto ${ }^{1}$, E. Rigon ${ }^{1}$, L. Mao $^{2}$, L. Picco ${ }^{1}$, F. Delai ${ }^{1}$, M. A. Lenzi ${ }^{1}$
}

4

$5{ }^{1}$ Dept. of Land, Environment, Agriculture and Forestry, University of Padova, Padova (Italy)

$6{ }^{2}$ Dept. of Ecosystems and Environment, Pontificia Universidad Católica de Chile, Santiago

7 (Chile)

$8{ }^{*}$ Corresponding author (email: johnny.moretto@studenti.unipd.it)

\title{
11 ABSTRACT
}

12 Many gravel bed rivers in the European Alpine area suffered different ranges and types

13 of human pressure that modified their morphology and altered their processes. This

14 work presents the case of the middle portion of the Brenta River, historically impacted

15 by human activities such as floodplain occupations, bank protection, gravel mining, 16 hydropower schemes and water diversion. Dam operation and gravel mining have 17 produced considerable modifications in the natural sediment regime generating 18 important morphological channel responses (narrowing and incision). Large areas of the 19 former active channel have been colonized by riparian vegetation, both as islands and as 20 marginal woodlands. Overall, the river changed its morphological pattern from braided 21 to wandering. The present study analyzes the timing and extent of the planform 22 morphological changes that occurred over the last 30 years along the middle portion of 23 the river (20 km long) through the examination of aerial photos, repeated topographic 24 measurements, and hydrodogical data. A series of recent aerial photos (1981, 1990, 
25 1994, 1999, 2003, 2006, 2008, 2010 and 2011) have been used to assess the medium

26 and short-term morphological changes of the floodplains and the active channel area. As

27 to the medium-term modification, the recent changes in in-channel gravel mining have

28 determined a new trend of active channel widening through erosion of vegetated areas.

29 The analysis has also allowed to assess the morphological effect of single flood events.

30 Only floods with RI higher than 8-10 years appear to be able to determine substantial

31 erosion of floodplain and island margins.

32 Keywords: planform changes, islands dynamics, human impact, floods, Brenta River.

33

34

35

36

37

38

\section{Introduction}

Over the last 200 years the most Italian and European rivers have suffered considerable human pressures both at the basin and channel scales (Liébault and Piégay, 2002; Gurnell et al., 2009; Surian et al., 2009a; Comiti et al., 2011). Phases of deforestation and reforestation, channelization, sediment mining, urbanization, dam building, torrent-control works, water diversion for agriculture and hydro-electric power generation, and many other interventions have modified natural water and sediment fluxes and boundary conditions. Sediment retention below dams and other minor structures can reach 50\% of the total sediment load (Surian, 1999; Liébault and Piégay, 2001; Globevnik and Mikoš, 2009). Deficit of sediment supply in many Italian rivers was aggravated by in-channel mining especially between 1960 and 1980 (Comiti et al., 2011). As a result, many Italian Alpine rivers, suffered a first, major phase of narrowing and incision followed by a more recent recovering widening trend (Surian and Rinaldi, 2003). For instance, in the Piave River natural and artificial reforestation (mainly after 
50 the 1950s) and erosion- and torrent-control works (after the 1970s), led to a strong river

51 narrowing during the last century and a change from braided to wandering/single-thread

52 morphology, leaving large areas available to the establishment of riparian forests

53 (Surian et al., 2009b; Comiti et al., 2011). Bed incision reached $1 \mathrm{~m}$ and bed width

54 decreased of about the $50 \%$ (Comiti et al., 2011).

55 The type and dynamics of islands in a riverine system can help to depict processes of 56 river changes and temporal evolution. Gurnell and Petts (2002) determined that most 57 European rivers were once islands-dominated (pre-1900), but have become devoid of 58 islands due to human interference. Away from areas of agricultural or urban 59 development in Europe, islands remain a common feature of riverine landscapes, such 60 as in the Tagliamento River in northeastern Italy (Ward et al., 1999). The presence of a 61 certain species of plant on the islands can help to determine the flow conditions in the 62 area. Some plant species require specific growth conditions, such as inundation 63 duration, gradient, and particle size (Picco et al., 2012, Bertoldi et al., 2011. The flows 64 of larger rivers are regulated to some degree. This can have implications for fluvial 65 islands development and stability. Dams reduce flood peaks, increase base flow, and 66 store sediments (Kondolf, 1997; Braatne et al., 2003), being the sediment transported 67 downstream of a dam only a fraction of the normal sediment load (Surian, 1999). This 68 also generally reduces the biologic habitat, diversity, and interactions between biotic 69 and hydrologic processes (Poff et al., 2007). While dams can reduce erosion and 70 destruction of fluvial islands, they also promote bank attachment by decreasing the 71 sediment supply and reducing the downstream transport capacity which leads to 72 deposition of tributary input sediment. 
73 This paper deals with the morphological evolution and the associated island dynamics 74 of the middle course of the Brenta River (from Bassano Del Grappa to Piazzola sul 75 Brenta) over the last 30 years. Previous studies in this river basin have analyzed: (i) 76 morphological changes of the river channel (Surian and Cisotto, 2007; Surian et al., 77 2009b; Moretto et al., 2011); (ii) land use changes within the fluvial corridor and the 78 abundance of in-channel wood (Comiti et al., 2006, 2008; Rigon et al., 2008, 2012; 79 Vitti et al., 2011); and (iii) sediment transport and sediment budget in the headwaters 80 (Lenzi et al., 2006, Mao and Lenzi, 2007). The evolution of the reach between Bassano 81 Del Grappa and Piazzola sul Brenta is interesting to be explored because it was heavily 82 affected by human pressure due to a dense hydropower scheme in the basin and severe 83 past gravel mining activity.

84 This paper adds novel findings to previous papers dealing with similar regulated Italian 85 rivers (e.g. Surian et al., 2009b; Comiti et al., 2011) on three aspects. Firstly, the paper 86 presents a combined analysis of lateral and vertical channel adjustments with islands 87 dynamics during the last 30 years; secondly, the varying channel response exhibited 88 along the study reach is analyzed and connected to natural as well as human-induced 89 factors at this scale. Finally, the paper takes advantage of evidences of channel changes 90 during the 2010-2011 period, characterized by two considerable flood events with 91 recurrence interval (RI) of 8 and 10 years.

92 The objectives of this paper are: (i) to quantify the geomorphic changes, both in bed 93 planform and in bed elevation; (ii) to analyze the islands dynamics; (iii) to identify the 94 driving factors of channel evolution and island dynamics changes thus envisaging the 95 most likely future trends; (iv) to explore chances and limitations of river restoration in 96 the studied reach. 


\section{General settings of the study area}

99

\subsection{Climatic, geological and morphological setting of the Brenta River basin}

The Brenta River is one of the most important rivers of the Southern Alps (Italy)

102 flowing into the upper Adriatic sea (Figure 1). The mountain drainage basin covers a 103 surface of $1567 \mathrm{~km}^{2}$. The river length is $174 \mathrm{~km}$ and can be divided into two main 104 reaches: an upper $70 \mathrm{~km}$ long stretch flowing within the mountain basin, and a $104 \mathrm{~km}$ 105 upper basin features a typical continental-Alpine climate with annual rainfall of about $1500 \mathrm{~mm}$ (Giuliacci et al., 2001). The geological setting is rather complex and includes before becoming meandering and then heavily rectified in its lower course.

112

\subsection{Human impacts within the Brenta River basin}

During the past centuries, the Brenta River has been affected by multi-spatial and temporal human interventions (Surian and Cisotto, 2007) which have heavily modified its natural characteristics. The magnitude and consequences of such disturbances have increased during the last 100 years. The human impacts consist mostly of direct interventions, such as channelization, gravel mining and dam, levees and groins et al., 2009b). In particular, gravel mining has been recognized as the human 
121 intervention with the greatest impact on channel morphology. This activity, which has

122 mostly occurred in the lower reaches especially between 1950 and 1980, removed a 123 large volume of sediments, exceeding replenishment rates and producing a significant 124 alteration in sediment fluxes (Surian and Cisotto, 2007). Indeed, official estimates set 125 volumes of extracted sediment to around 6-8 million $\mathrm{m}^{3}$ from 1953 to 1977 . However, 126 these values are most likely to be far underestimated (Castiglioni and Pellegrini, 2001).

127 The second most important human disturbance has been the construction of several 128 dams which have reduced both flow and sediment discharges. The largest dam, built in 1291954 for hydroelectric power generation and irrigation purposes, is the Corlo dam, in 130 the Cismon torrent, with its 42 million $\mathrm{m}^{3}$ reservoir (the main tributary of Brenta River).

131 It is also worth mentioning the impacts of torrent-control works in the low-order 132 mountain streams and the last trend of basin natural reforestation, which have reduced 133 the sediment yield at the basin scale contributing to channel incision. These impacts 134 resulted in the narrowing of the average river bed width from around $440 \mathrm{~m}$ at the 135 beginning of the $1800 \mathrm{~s}$ to around $220 \mathrm{~m}$ in 2003 and the remarkable channel incision of 136 up to $7 \mathrm{~m}$ (Surian and Cisotto, 2007).

\subsection{Study reach}

139 The Brenta River's reach considered in the present study is approximately $20 \mathrm{~km}$ 140 long and is located in the piedmont area of the basin (area of about $1567 \mathrm{~km}^{2}$ ) between 141 the cities of Bassano Del Grappa and Piazzola sul Brenta (Figure 1a). The upper part of 142 the reach, located immediately downstream of the mountain area, features a fairly 143 straight channel and a narrow alluvial plain. In its middle portion the river widens, the 144 slope is lower (about $0.3 \%$ ) and the river features a braided pattern with islands. In its 
145 lower part, the river exhibits a wandering pattern with higher sinuosity $(\approx 1.12)$ and the

146 presence of extensive riparian vegetation on floodplains. Within the study reach there is

147 a wide range of human infrastructures such as embankments, bridges, and transversal

148 works such as the Carturo transverse (located at the very end of the study reach). Also,

149 the floodplains are characterized by the presence of urbanized areas, and much of the

150 discharge is diverted for irrigation and hydroelectric purposes.

\section{Materials and methods}

154

155

156

157

158

159

160

161

162

163

164

165

166

167 banks and floodplains).

\subsection{Cross-sections and longitudinal profile}

Twelve historical cross-sections described in detail by Surian and Cisotto (2007) lie within the study reach (Figure 1a). They were first surveyed in 1932, and then in 1997 with a total-station device. In 2010, the first 10 cross-sections were re-surveyed with a DGPS with a maximum vertical error of $\pm 0.03 \mathrm{~m}$. Two Light Detection and Ranging (LiDAR) surveys taken in 2010 and 2011 are available for the study area. Further resurveys of the study cross-sections were derived from these data, taking advantage of the ground points of the filtered LiDAR data and the underwater points obtained by an image analysis of coloured aerial photos taken during the same flight (Moretto et al., 2012). The vertical error of these cross-sections was estimated to be around $\pm 0.15 \mathrm{~m}$. The longitudinal profile along the river reach was derived from an averaged crosssection elevation, calculated using all points within the active channel (i.e. excluding 


\subsection{Flow regime}

The Flow regime was measured at the basin outlet, Barzizza gauging station, by the former Italian National Hydrographical and Hydrological Agency from 1924 to 1996, and by ARPAV (Environment Protection Agency of Veneto Region), from 1997 to 2010. The station is located $5 \mathrm{~km}$ upstream of the analyzed reach (see Figure 1). Mean daily discharges (Q) were available for two periods: 1924-1996 and 2005-2011. From 1997 to 2004, Qd was obtained throught the application of the stage-discharge rating curve validated by ARPAV for the period 2005-2011. All values of the two series of data were checked and original missing data were calculated by cross-correlation and interpolation techniques (Kaless et al., 2011; Lenzi et al., 2010).

Nevertheless, values of water levels recorded at the Barzizza station, were not available for most part of the years 1942, 1943, 1944, 1945, 1946, 1967, 1968 and 1984 and was thus not possible to estimate mean daily water discharges by interpolation techniques (Figure 2).

A comparison between maximum instantaneous peak water discharge, maximum hourly daily water discharge and maximum main daily discharge, was carried out for 24 floods events measured in the field by the ARPAV, and occurred in the period 2004-2009. Flood events were chosen with the criteria of guaranteeing both the non-dependency between two consecutive floods (on the value of the peak discharge for each event) and to cover a large range of water discharge peak values. A very good correlation was obtained (Kaless et al., 2011) between the values of maximum hourly daily and maximum main daily water discharge $\left(r^{2}=0.96\right)$. Extending this analysis to the entire available data set, a total of seventy nine (79) flood events were chosen, checked and considered for testing different probability distribution functions and for the flood 
194 frequency-return time estimations (see point 4.2 Flow regime analysis).

195

196

\subsection{Identification of geomorphological and island features from aerial photos}

197 The evolution of islands and bed river morphologies over the last 30 years was analyzed taking advantage of nine series of aerial photos, acquired always during lowwater level conditions (see details of the photos in Table 1). Aerial photographs were rectified and co-registered to a common datum base at 1:5000 using a GIS software (ESRI $^{\circledR}$ ArcGIS 10). Approximately 40 ground-control points were used to rectify each single frame, and third-order polynomial transformations were then applied, obtaining root mean square errors (RMSE) ranging from 0.3 to $1 \mathrm{~m}$. The higher RMSE are for 1981, 1990 and 1999 (1 m of pixel size).

These photos were analyzed using the same method described in Comiti et al. (2011), in order to identify the active channel and islands extents along the whole $20 \mathrm{~km}$-long study reach. The active channel is defined as the area without shrub vegetation, thus including unvegetated bars and active and inactive channels, while the fluvial islands class include pioneer, young and stable islands according to Gurnell and Petts (2002)

classification. In order to analyze morphological changes along the study reach, active channel and islands widths were taken in 85 position, $250 \mathrm{~m}$ apart in transects 212 perpendicular to the river axis which were created in GIS environment.

\subsection{Photo-interpretation errors}

215 The errors related to the photo-interpretation assessment were performed using the 216 Mount et al. (2003) method. This procedure consists of the estimation of two 217 independent errors, the first represents the operator error associated with the bankline 
218 digitalization, while the second defines the uncertainty deriving from the air images.

219 Considering the first type, we multiplied the pixel resolution (R) by the mean of the 220 maximum number of pixels (p) of repeated right and left delineations of the bankline.

221 Given that the error range was below $2 \mathrm{~m}$ (among all photo sets), we decided to group 222 together the offset data for each set, reaching one average pixel error value (p). The 223 distortion degree within each air image was assessed by comparing positions (i.e. 224 building corners) easily identifiable on all photo sets with the same ones found on the 2252006 ortho-photographs. Finally the quantification of the distance difference was 226 carried out. Thus, the photo distortion error considering each image set $(\theta)$, represents 227 the mean distance difference between points. Concluding the process of error 228 identification, the total error in width $\left(\mathrm{E}_{\mathrm{w}}\right)$ was assessed by Mount et al. (2003) 229 equation:

$$
\mathrm{E}_{\mathrm{w}}=2^{1 / 2} \mathrm{pR}+2 \theta
$$

231 Accounting for the polygonal areal error (erosion, channel, islands), we needed to set 232 two assumptions: (1) the constancy (no error) of eroded bank segments, channel length 233 or islands and (2) the rectangular form of the polygons describing these areas. In this 234 sense, the assessment error related to the area was equal to the product between the 235 polygon length and the width error (Mount et al., 2003).

237 4. Results

2394.1 Flow regime analysis

240 The RI of each flood was estimated from the maximum annual values of the mean

241 daily water discharge (Qd) over 79 considered hydrological years. Various functions of 
242 the hydrological probability distribution were tested and the Gumbel distribution (OLS)

243 was chosen, due to the best performance of the Kolmogoroff test. The bankfull 244 discharge $(\mathrm{RI} \sim 1.5$ years $)$ was calculated around $350 \mathrm{~m}^{3} \mathrm{~s}^{-1}\left(\mathrm{Q}_{1.5}\right)$, which is esceeded 2452.4 days per year, and the discharge with RI of 10 years was estimated to about $750 \mathrm{~m}^{3}$ $246 \mathrm{~s}^{-1}\left(\mathrm{Q}_{10}\right)$. The largest flood event was registered on the $4^{\text {th }}$ of November 1966, with 1330 $247 \mathrm{~m}^{3} \mathrm{~s}^{-1}$ as mean daily discharge (RI $\sim 200$ years).

248 The flow regime of the Brenta River is characterized by rainfall and snowmelt 249 contributions in spring and by autumn rainfall (Lenzi et al., 2010; Kaless et al., 2011). 250 Also, flood events tend to occur in May, October and November, when more than 50\% 251 of all flood events recorded from 1924 to 2011 occurred (Lenzi et al., 2010; Kaless et $252 a l ., 2011)$.

253 Over the last thirty years, four flood events with RI equal or greater than 10 years were 254 registered (1980, 1996, 2002 and 2010). Two severe flood events occurred in November 255 and December 2010. The first flood, caused by prolonged and extended rainfall, lasted 256 from $31^{\text {st }}$ October to $2^{\text {nd }}$ November 2010 , with peak discharge of about $720 \mathrm{~m}^{3} \mathrm{~s}^{-1}$ (RI 2578 years). The second flood, originated by intense precipitations occurred between $21^{\text {st }}$ 258 and $26^{\text {th }}$ December 2010 and peaked at $759 \mathrm{~m}^{3} \mathrm{~s}^{-1}$.

259

260

261

262

263

\subsection{Bed-level changes along the study reach}

The vertical adjustment of the river bed was analyzed using the 10 historical crosssections measured from 1932 to 2010, along with results coming from LiDAR analysis carried out by Moretto et al. (2012). If compared with the profile of 1932 (Figure 3) it 264 appears that, as already highlighted by Surian and Cisotto (2007), the river experienced 265 incision up to 5-8 meters except for section 1, where vertical adjustments were lower 
266 than $-0.35 \mathrm{~m}$. Instead, over the last 13 years (1997-2010), the river bed experienced a 267 general incision of around $0.2 \mathrm{~m}$. However, significant differences in vertical 268 adjustments appear along the reach. In fact, in the upstream portion of the study reach, 269 from section 1 to 5, average vertical adjustments of the active-channel during the last 270 thirteen years range from $-0.35 \mathrm{~m}$ (section 1) to $-0.92 \mathrm{~m}$ (section 2), with an average of $2710.7 \mathrm{~m}$ (average level of the active channel). If the talweg line is considered (table 2), the 272 largest incision of the river is equal to $1.78 \mathrm{~m}$ in correspondence of section 1 . The 273 middle portion of the study reach seems to be in an equilibrium condition since a 274 vertical variation of only $-0.01 \mathrm{~m}$ and $0.11 \mathrm{~m}$ occurred on section 6 and 7 , respectively. 275 Conversely, the lower portion of the study reach has been aggrading from 1997 to 2010, 276 since the mean level of the last three historical sections $(8,9$, and 10$)$ has raised between $2770.42 \mathrm{~m}$ and $0.48 \mathrm{~m}$. The largest aggradation of the river along the talweg (table 2) in the 278 period 1997-2010 was reached by section 7 with $0.69 \mathrm{~m}$. The channel slope of the 279 whole study reach remained virtually constant from 1997 to 2010, passing from 0.0036 $280 \mathrm{~m} \mathrm{~m}^{-1}$ to $0.00356 \mathrm{~m} \mathrm{~m}^{-1}$ with a relative variation of only $1 \%$.

281 The analysis of the cross-sections derived from the 2011 LiDAR survey (Moretto et al., 282 2012) confirmed the vertical adjustment trends from 1997 to 2010 (Figure 3). The mean 283 elevation of sections 2 and 5 experienced a further reduction ( 5 and $8 \mathrm{~cm}$, respectively), 284 and section 7 increased its elevation of $14 \mathrm{~cm}$, if compared to 2010. However, it should 285 be noted that the 2011 cross-sections could be affected by a greater error in respect to 286 those of 2010 since they are derived from the LiDAR survey. In Figure 4, sections 2, 5, 287 and 7 (as representative of the upper, middle and down-stream part of the study reach) 288 are shown, and the horizontal line represents the bankfull level as surveyed in the field 289 in 2010. Incision and narrowing tendencies are evident in the three cross-sections. In 
290 section 5 (Figure 4b), the main channel shifted progressively leftwards and reached the 291 main embankment. A different behavior in the lower portion of the reach is evidenced 292 by the fact that section 7 (Figure 4c) remained fairly unchanged over the last 13 years.

293

294

\subsection{Changes of active channel area and width along the study reach}

The analysis of the extent of active channel conducted by using aerial photos has confirmed remarkable fluctuations during the last 30 years (Figure 5). Five significant 297 periods characterized by different dynamics of active channel changes could be 298 identified: 1981-1990, 1990-2003, 2003-2008, 2008-2010 and 2010-2011. The first and third periods are characterized by a decrease of active channel surface (-148 ha and -70 ha, respectively), whereas the second, the fourth, and the fifth periods are characterized by an increase of the active channel surface (135 ha, 10 ha and 41 ha, respectively). 302 Figure 6 depicts the longitudinal variation of active channel width within the 5 303 identified periods of different morphological behavior. The average values of channel 304 width for the entire analyzed reach in 1981, 1990, 1999, 2003, 2006, 2008, 2010 and 3052011 have respectively the following values: 266, 181, 197, 226, 225, 200, 196 and 215 306 m. During the first nine years of the analyzed period (1981-1990), the average active 307 channel width decreased from $266 \mathrm{~m}$ to $181 \mathrm{~m}\left(9.44 \mathrm{~m} \mathrm{year}^{-1}\right)$. The active channel narrowing seems to have occurred along the whole river reach, except for a rather marked enlargement occurred near the $7^{\text {th }}$ section (Figure 6). In the period 1990-2003 there was an inverse tendency, characterized by an increase of the average width, up to $16 \mathrm{~m}$ (from 1990 to 1999 , at the rate of $1.78 \mathrm{~m} \mathrm{year}^{-1}$ ) and then of a further $29 \mathrm{~m}$ from 1999 to 2003 ( $\left.7.25 \mathrm{~m} \mathrm{year}^{-1}\right)$. The average widening trend was not uniformly distributed along the reach, but appears to be more concentrated between the fourth and thirteenth 
$314 \mathrm{~km}$. In the most recent years (2003-2008) the active channel width reduced again from

$315226 \mathrm{~m}$ to $200 \mathrm{~m}\left(5.2 \mathrm{~m} \mathrm{year}^{-1}\right)$. This average trend is mainly due to intense localized

316 narrowing processes occurred around the thirteenth $\mathrm{km}$, while in the rest of the channel

317 the width remained fairly constant. During the period 2008-2010, there was a slight

318 narrowing concentrated at about the thirteenth and eighteenth $\mathrm{km}$ along the studied

319 reach from $200 \mathrm{~m}$ to $196 \mathrm{~m}\left(2 \mathrm{~m} \mathrm{year}^{-1}\right)$, followed by a very recent enlargement phase

320 between 2010 and 2011 from $196 \mathrm{~m}$ to $215 \mathrm{~m}$, respectively, with a rate equal to $19 \mathrm{~m}$

321 year ${ }^{-1}$ which is the largest variation registered in the last thirty years. Overall, the active

322 channel width reduced by $51 \mathrm{~m}$ from 1981 to 2011 , even if different temporal trends are

323 observed during the studied period and along the reach. It is worth noticing the effect of

324 November and December 2010 floods (RI = 8 and 10 years, Lenzi et al., 2010), which

325 caused channel widening fairly distributed along the whole reach (Figure 6).

326

3274.4 Changes of islands area and width along the study reach

328 The extension of islands within the entire reach (Figure 5 and 7) was calculated, as

329 for the active channel area, by photo-interpretation from the historical series of aerial

330 photos from 1981 to 2011 . Changes in island area reflect the trend of the active channel

331 area (Figure 5) but it is not uniform along the whole reach (Figure 7). The first phase

332 from 1981 to 1990 is characterized by an increase of 77 ha of islands and a decrease of

333 the active channel. This appears to be more concentrated around sections 2 and 5 and

334 below section 7 . The second phase from 1990 to 2003 is characterized by 14 over-

335 bankfull floods (with one $>10$ years RI in 2002), and features a marked decrease of

336 islands area (-52 ha). Afterwards, due to the lack of high-magnitude floods from 2003 to

3372008 , the areal extent of islands increased (52 ha), being this expansion relativelly

338 uniform in whole reach. The phase from 2008 to 2010 is characterized by a reduction of 
33917 ha of islands area, bringing the overall distribution of them in a similar situation as in 3402003 . The only exception is for a new relevant island area between the $17^{\text {th }}$ and $18^{\text {th }} \mathrm{km}$ 341 from section 1 (Figure 7 - 2008 vs. 2010), Subsequently, another decrease phase of 342 about 10 ha from 2010 to 2011 , more marked from the beginning of the study reach to 343 the $7^{\text {th }}$ cross-section.

344 Major island extension values (108 ha in 1990 and in 2008) are associated with the 345 major narrowing of the active channel (341 ha in 1990 and 405 ha in 2008). On the 346 opposite, the minimum islands extension coincides with the maximum extent of the 347 active area (1981), equal to $51 \%$ of the entire area of the river corridor.

\section{Discussion}

351

352

353

354

355

356 and vertical adjustments of the active channel extent of 10 cross-sections are depicted. In the period 1932-1997, which corresponds to the incision/narrowing phase (except for section 1), vertical and lateral adjustments are not significantly correlated (R Spearman;

5.1. Vertical and lateral adjustments along the middle portion of Brenta River over the last 30 years.

The relationship between the vertical adjustment of the average elevation of crosssections and the associated changes of active channel width was evaluated using ten historical cross-sections and considering two different periods: 1932-1997, and 19972010. Aerial photos of 1999 and 2010 were also used in order to improve the interpretation of the active channel width of cross-sections (Table 2). In Figure 8, lateral $p>>0.05)$. Channel incision and narrowing processes occurred at the same time in other 
363 Italian rivers as, for example, the Piave, the Po and the Tevere (Surian and Rinaldi, 364 2003). The weak correlation between vertical and planimetric adjustments over the last 36530 years in the Brenta River could be related to the different temporal and spatial extent 366 of the sediment dynamic processes. Similar processes occurred in the Piave River, 367 which for instance experienced channel widening and incision at the same time from 3681991 to 2006 (Comiti et al., 2011). The decoupled tendencies of vertical and lateral 369 adjustment may be due to the fact that morphological variations can be very different at 370 the sub-reach scale because of local constraints. Changes in active channel width were 371 very different in the period 1997-2010, being the narrowing phase finished (Figure 8), 372 and being some sections even widening (sections 2 to 5). Within the general widening 373 trend over the recent 5 years, the upper reach part (except for section 1) experienced 374 channel incision. This seems to be related to the paucity of sediment supply coming 375 from upstream reaches due to the low connectivity with the mountain reach (Surian et 376 al., 2009a). In some portions of the upper reach (e.g. section 2), the severe incision (up 377 to $5 \mathrm{~m}$ ) has probably lead to reach a very coarse sub-layer, and the bed appears 378 remarkably armoured (and possibly non completely alluvial), leading to a prevalent 379 tendency to erode the banks rather than to further incise the channel. In the downstream 380 reaches, where aggradation or equilibrium tendency are dominant, active channel is not 381 widening, most likely due to two reasons: i) the longitudinal control works (built since 382 the 1960s) greatly reduce the possibility of lateral migration of the river; ii) a mature 383 riparian vegetation next to the active channel that stabilize the soil and reduce bank 384 erosion. 


\subsection{Are flood events the main driving factor of channel changes and islands dynamics}

387

388

389

390

391

392

393

394

395

396

397

398

399

400

401

402

403

404

405

406

407

408

409

in the Brenta River?

Looking at the multi-temporal analysis of the active channel width conducted using aerial photos taken from 1981 to 2011 , a certain correspondence between widening trends of the active channel and the occurrence of flood events appears to exist (Figure 9). If the lateral annual adjustment $\left(\mathrm{m} \mathrm{year}^{-1}\right)$ is related with the average of annual daily peak discharge over the photo period registered at the Barzizza gauging station for the analyzed photo period, a directly proportional relationship seem emerges (Figure 10), showing that at higher magnitude of flooding corresponds a stronger active channel widening. Minimum channel widening value of $1.5 \mathrm{~m}$ is obtained only with $\mathrm{Qd}_{\text {mean }}$ over $450 \mathrm{~m}^{3} \mathrm{~s}^{-1}$. Active channel narrowing is clearly due to the expansion of riparian vegetation in floodplains and islands during periods lacking major disturbing processes $\left(r^{2}=0.87\right.$; Figure 10). Higher correlation is obtained $\left(r^{2}=0.91\right)$ if the lateral adjustment rate is related to the number of the days per year where $Q$ is greater than $450 \mathrm{~m}^{3} \mathrm{~s}^{-1}$, over the step time (Figure 11). For the period 1999-2003 (1407 days), 13 days with Qd over $450 \mathrm{~m}^{3} \mathrm{~s}^{-1}$ were registered (3.4 days per year) and a widening of 7.4 meters per year was observed. A greater lateral adjustment rate of about $31.2 \mathrm{~m} \mathrm{year}^{-1}$ was calculated for the step time 2010-2011 (225 days), with 6 days of Qd over the the threshold value of $450 \mathrm{~m}^{3} \mathrm{~s}^{-1}$ (Figure 11). Two major floods (RI> 10 years) occurred on each of these periods.

Overall, it appears that floods events with mean daily discharges (Q) around $750 \mathrm{~m}^{3}$ $\mathrm{s}^{-1}(\mathrm{RI} \sim 10$ years $)$ were able to cause evident widening of the bankfull section $(>10-20$ m). A similar flood magnitude has been reported by Comiti et al. (2011), that quantified in 10 years the RI flood needed to modify considerably the fluvial planimetric shape, 
410 especially floodplains and islands, in the Piave River. Further studies confirmed that 411 island reduction processes take place due to flood events of considerable ( $>10$ years) 412 magnitude (Bertoldi et al., 2009; Surian et al., 2009b; Comiti et al., 2011; Vitti et al., 413 2011; Picco et al., 2012.

414 Despite the fact that natural channel adjustments at the reach scale are mainly due to the 415 occurrence of floods events, a fundamental role is also played by the individual 416 characteristics of each small reach (Figure 6), which can strongly influence the change 417 responses in the different portions of the river. Overall, differences in adjustment 418 responses to the 2010-2011 flood events along the reach could be linked to different 419 physical settings (especially bed slope), but also to the disturbance in sediment flux and 420 sediment availability from upstream reaches. The higher erosional trend (Figure 4) in 421 the upper part of the study reach is likely due to the higher physical constrains which do 422 not allow the channel to migrate. In fact, human structures aimed at protecting the 423 nearby areas against floods (e.g., embankments, groins, and rip raps), are most likely to 424 have reduced the active channel width, causing severe incision as partially confirmed by 425 the recent multi-temporal analysis. The concentrated bank erosion could be enhanced by 426 both the alteration of sediment flux due to the low connectivity with the upstream 427 drainage basin already identified by Surian et al., (2009b), and by the scarcity of 428 vegetation growing on the banks. Sediment supply to the upstream reach is very low 429 due to the presence of dams and torrent control works in the mountain basin. As a 430 result, the connectivity with the upstream basin is virtually negligible for bedload and 431 coarse sediment input to this sub-reach (cross-section 2). Moreover, a knickpoint in the 432 longitudinal profile appears around cross section 3, located $4.4 \mathrm{~km}$ downstream section 4331 , indicating that this portion of the river is likely in a current transient condition to 
434 equilibrium. Channel incision in the upper part of the study reach is than likelly 435 continue until a urther adjustment of slope, or unitl a further development of armour 436 layer.

437 The application of a 2D hydrodynamic and morphodinamic model for gravel bed rivers 438 recently developed by Kaless (2012), to the Brenta River's Nove sub-reach (around 439 section 2), indicates that the most probable short-term evolution of the reach will 440 depend on the floods magnitude. Ordinary events (discharges below $450 \mathrm{~m}^{3} \mathrm{~s}^{-1}$ ) will 441 produce negligible changes within the channel bed. On the other hand, more infrequent 442 floods (RI > 10 years), are expected to produce remarkable banks erosion. Widening is 443 the main processes able to stabilize the channel owing to the reduction in shear stress 444 and the delivery of sediment into the channel.

445 In the middle portion of the study reach (around cross-section 5), the channel has 446 recently been realivelly stable, likely because in-channel mining hasn't longer been 447 carried out since 1992-1994, and significant bank erosion has recently occurred in the 448 upstream sub-reach, supplying eroded sediments and coarse material. In fact, the sub449 reach around cross-section 6 appears to have been stable over the past few years (Figure 4503 and 8), suggesting that major sediment supply is not to be expected in the further 451 downstream reach. Indeed, gravel mining activities were not intensive in this part in the 452 past, and enough volumes of coarse and fine sediments are available from bank erosion 453 of the upper part of the study area.

454 Generally, it appears that portions of the study reach with lower human disturbances 455 and structural constraints are currently widening, whereas reaches heavily constrained 456 are still suffering considerable erosion processes (Figure 4 and 6). The dominance of 457 erosional processes in the upstream and a general stability depositional phase on the 
458 downstream portion of the study reach is also reflected by the different islands 459 dynamics. In the far downstream reach, (around section 7), the sediment deposition and 460 the higher morphological stability creates suitable conditions for the stabilization of 461 vegetation, while other active channel areas are more disturbed by floods and the islands 462 are more affected by erosion processes. Beyond these aspects, it's worth considering the 463 relevant influence of direct human actions (e.g. vegetation removal, local clearcuttings, 464 bank protections, agricultural settlements, recreational areas) which are still present 465 along the river corridor and can modify locally both the morphological and vegetation 466 dynamics (Picco et al., 2012). The analyzed fluvial system is the result of centuries of 467 alterations, as highlighted for other rivers of the Veneto Region (Comiti et al., 2011). In 468 the period 1990-2011, the fluvial dynamics of the Brenta River appears to be less 469 affected by human alterations, due particularly to the decrease or almost the 470 abandonment of mining activities within the channel.

471

472 5.3. Driving factors of channel evolution over the last 30 years and implications for 473 channel recovery

474 The study reach of the Brenta River was characterized by a period of strong 475 narrowing of the active channel (from 1981 to 1990) followed by a general stability and 476 an initial, low recovery phase (Figure 5). A similar situation was found in the Piave 477 River (Comiti et al., 2011). Analyzing in detail this trend, five periods can be identified 478 (1981-1990, 1990-2003, 2003-2008, 2008-2010 and 2010-2011). Comparing the surface 479 extension of the active channel at the beginning and at the end of each series, it was 480 possible to highlight and calculate erosion and deposition areas. Figure 5 reports 481 enlargement and narrowing areas and the total areal variation of the active channel. In 
482 the first nine years (1981-1990), the active channel decreases of $\sim 225$ ha, equal to $19 \%$

483 of the total area, with a variation rate of 25 ha year ${ }^{-1}$ which represents the smaller 484 historical extension. This period corresponds to a series of ordinary flood events 485 (average annual hourly peak discharge 1981-1990 $=426 \mathrm{~m}^{3} \mathrm{~s}^{-1}$, maximum $\mathrm{Qh}=682 \mathrm{~m}^{3}$ $486 \mathrm{~s}^{-1}$ ) and still relevant human impacts. The 1990s coincide with the end of the narrowing 487 phase, commonly associated, for Italian rivers, to sediment mining activities (Surian et 488 al., 2009b). Some differences are noticeable with other Alpine regions where floodplain 489 reforestation (following changes in the land use), along with sediment mining, is 490 considered a major cause of channel erosion (Liébeault and Piégay, 2001, 2002; Rinaldi 491 et al., 2011). As showed by the most recent channel evolution of the Brenta River, 492 Surian and Rinaldi (2004) identified a phase of channel widening in several Italian 493 rivers and Surian et al., (2009b) pointed out that such phase is often associated with 494 aggradation, even if it can also occur without significant bed level changes. A similar 495 phase in our study site can be recognized from 1990 to 2003. In this period, there was a 496 partial recovery of the active channel width of $\sim 135$ ha (11\% of total area, 11 ha year $49{ }^{1}$ ), eventually due to flood events (e.g. 2002 and 1996) and/or a partial recovery of the 498 natural dynamics (in relation with the decrease of gravel mining and human pressure). 499 During these 12 years, in fact, we can observe an increase of the most intense flood 500 events (average annual hourly peak discharge 1990-2003 $=572 \mathrm{~m}^{3} \mathrm{~s}^{-1}$, maximum Qh $501 \quad 1990-2003=860 \mathrm{~m}^{3} \mathrm{~s}^{-1}$ and 6 floods with $\mathrm{RI} \geq 5$ year). During the third period (2003502 2008), the trend changes one more time as demonstrated by the multi-temporal analysis 503 of the aerial photos (Figure 5 and 9): the active channel surface reduces of $\sim 70$ ha (14 504 ha year ${ }^{-1}$ ) which corresponds to about $6 \%$ of the total area. In this period, the flows 
505 decrease their intensity (average annual hourly peak discharge 2003-2008 $=425 \mathrm{~m}^{3} \mathrm{~s}^{-1}$, 506 maximum Qh 2003-2008 $=618 \mathrm{~m}^{3} \mathrm{~s}^{-1}$ ), and no flood events with RI $>4$ years occur.

507 Observing the fourth period (2008-2010), we can notice a new little expansion of 10 ha, 508 that corresponds to about $1 \%$, due to two subsequent floods of around $327 \mathrm{~m}^{3} \mathrm{~s}^{-1}$ and $509676 \mathrm{~m}^{3} \mathrm{~s}^{-1}$, in 2008 and 2009, respectivelly. During the last period (2010-2011) there 510 was a consistent enlargement of about 41 ha, that correspond to about $3 \%$, due to the 511 significant 2010 flood $\left(\mathrm{Qh}=863 \mathrm{~m}^{3} \mathrm{~s}^{-1} ; \mathrm{Qd}=759 \mathrm{~m}^{3} \mathrm{~s}^{-1}\right.$ with $\mathrm{RI}=10$ years $)$. In 512 correspondence to this enlargement, a low channel incision in the upper part of the 513 study reach is recognizable. On the contrary, in the second half of the reach a relative 514 phase of equilibrium or smooth aggradation can be distinguished (see section 4.2 and 515 Figure 3). Contrary to the Piave River which is currently showing a certain 516 morphological recovery (Comiti et al., 2011); the Brenta River is not entirely in a 517 morphological recovery trajectory. Even though in the downstream area of Bassano Del 518 Grappa the abandonment of gravel mining activities has led to a decrease of erosion and 519 narrowing processes starting from the early 1990s, a low morphological degradation of 520 the river is still undergoing. The main recognizable driving factors seem to be: i) the 521 very scarce availability of bedload transported sediment from upstream (as highlighted 522 also in Surian and Cisotto, 2007); ii) the absence of tributaries which can supply 523 sediment; iii) the higher bedload transport capacity consecuent to the increase of slope 524 registered from 1997 until so far $(+0.3 \%$ o). In the downstream part, otherwise, the 525 active channel results much more stable, either in width and elevation terms due to: i) 526 the higher availability of sediment which derives from the upstream part as consequence 527 of bank and bed erosion; ii) the lower slope (reduction of $0.6 \%$ ) of the active channel if 528 compared to 1997 from section 6 ahead; iii) the greater presence of stable riparian 
529 vegetation; iv) the reduction of sediment mobility carried out by numerous 530 infrastructures as bridges and dam structures (Carturo dam built up in the 1970s). The 531 recent variations of morphology and vegetation are related to the episodic severe flood 532 events, in association with the effects of human actions acting both at reach- (in the 533 past) and basin-scale (nowadays).

534 In order to avoid the adverse effects associated with the morphological deterioration 535 experienced by the river over the past, it seems that the management strategy should 536 pursue channel aggradation and promote bankfull expansion. These objectives could be 537 achieved through a proper management of sediment with measures oriented to: i) 538 prevent the extraction of gravel from the active channel and, if possible, locate these 539 activities upstream of the dams, favoring the transfer to downstream of trapped 540 sediment in the reservoir (Palmieri et al., 2001); ii) rethink about torrent control 541 measurements, promoting open check-dams with hydrodynamic filtering mechanism 542 (Conesa-Garcìa and Lenzi, 2010; D’Agostino et al., 2004); iii) promote the formation of 543 an erodible river corridor (Piégay et al., 2005), avoiding to occupy areas within the 544 levees with historical structures or agricultural activities; iv) go back to manage the 545 forest in mountainous areas, so as to promote recruitment processes of sediment from 546 the slope. The moderate recovery that the Brenta River is experiencing, especially in the 547 second half of the downstream reach analyzed (Surian et al., 2009b), is likely to 548 continue and increase only if a combinations of the actions described above will be 549 applied.

\section{Conclusion}


554 The medium and short-term morhological dynamics, channel width, channel slope 555 and islands of the study reach of Brenta River are remarkably complex due to the 556 occurrence of spatially variable natural processes and human disturbances. During the 557 study period a widening phase of the active channel has been observed, along with a 558 reduction of island extension from 1990 to 2003 and from 2008 to 2011. On the other 559 hand, from 1981 to 1990 and from 2003 to 2008, the river experienced channel 560 narrowing and island expansion. However, due to the relevant spatial variability of 561 morphological patterns, slope, and extent of human structures and disturbances these 562 dynamics and temporal trends are quite different along the study reach, that results in a 563 different morphological evolution in terms of channel width and island extent. Also, the 564 channel slope increased in the upper portion from $0.495 \%$ to $0.526 \%$ and decrease in 565 the lower portion of the study reach from $0.429 \%$ to $0.374 \%$. Overall, it seems that the 566 evolution trends of these two portion depend on sediment supply from upstream reaches 567 and from the types and degree of local human disturbances and infrastructures.

568 Alteration on sediment supply that drives recent channel and islands changes is related 569 to the extraction of sediment, indeed after the abandonment of mining in the river bed 570 (90s), the Brenta River has partially recovered its morphology. However, this trend is 571 not yet stable and not distributed along the whole study reach. In the upstream area there 572 are still incision and widening processes of the active channel as a result of bank 573 erosion. Recent changes in the active channel dimension are related to the rates of flood 574 events. The analysis of the relation between active channel adjustement and the 575 occurrence of flood highlights that severe flood events (RI >8-10 years) cause 576 substantial morphological modifications and erosion tends to reduce along downstream 
577 reaches. A more detailed and thoughtful sediment budget assessment, to be compared 578 with field measurements of sediment transport, is currently in progress and will be part 579 of a future publication.

580 The study suggests that restoration strategies could enhance channel recovery, but their 581 effectiveness will likely depend on the local human impacts and sediment availability 582 from upstream reaches. The upper reach (around section 2) is characterized by a very 583 reduced sediment supply from upstream due to a transversal barrier and by numerous 584 longitudinal defenses, which will prevent a natural widening and recovery. Moreover, 585 the region at the knick point in slope is still subject to a little degradation, indicated that 586 the river in this part is not entirely at equilibrium conditions. Instead, in the 587 downstream, is already widening and aggrading due to sediment supply from the upper 588 and middle reaches, the stabilization of the bed slope and the lower human disturbances, 589 thus restoration strategies (e.g. elimination of bank defenses) will probably increase 590 these natural tendencies.

591

592

593 Acknowledgements

594 This research has been carried out within the frame of the excellence project 595 "CARIPARO, Linking geomorphological processes and vegetation dynamics in gravel596 bed rivers". A part of field activity has been supported also by the strategic project of 597 the University of Padua, "GEORISKS, Geological, morphological and hydrological 598 processes: monitoring, modeling and impact in the North-Eastern Italy", 599 STPD08RWBY-004. Thanks to Emil Vincenzi and Nicola Surian for the support given 600 in the 2006 photointerpretation. All colleagues and students who helped in the field are 
601 greatly thanked. We greatly thanks the reviewers whose suggestions greatly improved 602 the original manuscript.

603

604

\section{References}

606 Bertoldi W, Gurnell A, Surian N, Tockner K, Ziliani L, Zolezzi G. 2009. Understanding

607 reference processes: linkages between river flows, sediment dynamics and vegetated 608 landforms along the Tagliamento River, Italy. River Research and Applications 25: $609 \quad 501-516$.

610 Bertoldi W, Drake NA, Gurnell AM. 2011. Interactions between river flows and 611 colonizing vegetation on a braided river: exploring spatial and temporal dynamics in 612 riparian vegetation cover using satellite data. Earth Surf. Processes and Landforms 36: $613 \quad 1474-1486$.

614 Braatne JH, Rood SB, Simons RK, Gom LA, Canali GE. 2003. Ecology of riparian 615 vegetation of the Hells Canyon corridor of the Snake River: field data, analysis and 616 modeling of plantresponses to inundation and regulated flows. Technical Report 617 Appendix E. 3: 3-3. Idaho Power Company. Boise, Idaho, USA.

618 Castiglioni, GB, Pellegrini GB. 2001. Note illustrative della carta geomorfologica della 619 Pianura Padana. Suppl. Geogr. Fis. Dinam. Quat., IV: 207.

620 Comiti F, Andreoli A, Lenzi MA, Mao L. 2006. Spatial density and characteristics of 621 woody debris in five mountain rivers of the Dolomites (Italian Alps). Geomorphology $622 \quad 78: 44-63$.

623 Comiti F, Pecorari E, Mao L, Picco L, Rigon E, Lenzi MA. 2008. New methods for 624 determining wood storage and mobility in large gravel-bed rivers. EPIC FORCE 
625 Project Report (D20bis). University of Padua, Padua, Italy. 626 (http://www.tesaf.unipd.it/epicforce/Download.asp).

627 Comiti, F, Da Canal M, Surian N, Mao L, Picco L, Lenzi MA. 2011. Channel 628 adjustments and vegetation cover dynamics in a large gravel bed river over the last 629200 years. Geomorphology 125: 147-159.

630 Conesa-Garcìa C, Lenzi MA (Eds.), 2010. Check Dams, Morphological Adjustments 631 and Erosion Control in Torrential Streams. Nova Science Publishers, New York, pp. 632298.

633 D'Agostino V, Dalla Fontana G, Ferro V, Milano V, Pagliara S. 2004. Briglie aperte. In 634 Opere di sistemazione idraulico-forestali a basso impatto ambientale, Ferro V, Dalla 635 Fontana G, Pagliara S, Puglisi S, Scotton P (eds). McGraw-Hill: Milano: 283-384.

636 Giuliacci M, Abelli S, Dipierro G. 2001. Il clima dell'Italia nell'ultimo ventennio, Alpha 637 test, Milano pp. 344.

638 Globevnik L, Mikoš M. 2009. Boundary conditions of morphodynamic processes in the 639 Mura River in Slovenia. Catena 79: 265-276.

640 Gurnell AM, Petts GE. 2002. Island-dominated landscapes of large floodplain rivers, a 641 European perspective. Freshwater Biology 47: 581-600.

642 Gurnell A, Surian N, Zanoni L. 2009. Multi-thread river channels: a perspective on 643 changing European alpine river systems. Aquatic Sciences 71: 253-265.

644 Kaless G, Mao L, Lenzi MA . 2011. Regime theories in gravel bed rivers; preliminary 645 comparison between disturbed rivers due to antrophic activities (Northeastern Italy) 646 and natural rivers (Patagonia, Argentina). Proceedings of the Intermediate Congress of 647 the Italian Association of Agricultural Engineering; Belgirate, Italy; September 22-24, $648 \quad 2011 ;$ pp. 8. 
649 Kaless G., 2012. Stability analysis of gravel bed rivers: caomparison between natural 650 rivers and disturbed rivers due to human activities. $\mathrm{PhD}$ Thesis; University of Padova, 651 Italy, pp. 275.

652 Kondolf GM. 1997. Hungry water: effects of dams and gravel mining on river channels. 653 Environ. Mgmt, 21-4-1997: 533-551.

654 Lenzi MA. 2006. Research developments in debris flow monitoring, modeling and 655 hazard assessment in Italian mountain catchments. WIT Transactions on Ecology and 656 the Environment 90: 135-145.

657 Lenzi MA, Mao L, Comiti F. 2006. Effective discharge for sediment transport in a 658 mountain river: computational approaches and geomorphic effectiveness. Journal of 659 Hydrology 326: 257-276.

660 Lenzi MA, Mao L, Comiti F, Rigon E, Picco L, Vitti P, Moretto J., Sigolo C. 2010. 661 Scientific contribution by the Research Unit Land and Agro-forest Department, to the 662 research activities carried out in the framework of the CARIPARO Project "Linking 663 geomorphological processes and vegetation dynamics in gravel-bed rivers", from 664 September 2009 to October 2010. Research and Technical Report; Department of 665 Land and Agro-forest Environment, University of Padova, Padova, Italy, pp. 102.

666 Liébault F, Piégay, H. 2001. Assessment of channel changes due to long-term bedload 667 supply decrease, Roubion River, France. Geomorphology 36: 167-186.

668 Liébault F, Piégay H. 2002. Causes of 20th century channel narrowing in mountain and 669 piedmont rivers of southeastern France. Earth Surface Processes and Landforms 27: $670 \quad 425-444$.

671 Mao L, Lenzi MA. 2007. Sediment mobility and bed load transport conditions in alpine 672 streams. Hydrological Processes 21: 1882-1891. 
673 Moretto J, Rigon E, Lenzi MA. 2011. Dinamica evolutiva di medio e breve termine 674 della vegetazione riparia e della morfologia d'alveo del F. Brenta. Proceedings of the 675 Intermediate Congress of the Italian Association of Agricultural Engineering; 676 Belgirate, Italy; September 22-24, 2011; pp. 1-6.

677 Moretto J, Delai F, Rigon E, Picco L, Mao L, Lenzi MA. 2012. Assessing short term 678 erosion-deposition processes of the Brenta River using LiDAR surveys. WIT 679 Transactions on Engineering Sciences, Vol 73, 149-160; doi: 10.2425/DEB120131; $680 \quad$ ISSN 1743-3533.

681 Mount NJ, Louis J, Teeuw RM, Zukowskyj PM, Stott T. 2003. Estimation of error in 682 bankfull width comparison from temporally sequenced and corrected aerial 683 photographs. Geomorphology 56: 65-77.

684 Palmieri A, Shah F, Dinar A. 2001. Economics of reservoir sedimentation and 685 sustainable management of dams. Journal of Environmental Management 61: 149686163.

687 Picco L, Mao L, Rigon E, Moretto J, Ravazzolo D, Delai F, Lenzi MA. 2012a. Medium 688 term fluvial island evolution in relation with flood events in the Piave River. WIT 689 Transactions on Engineering Sciences, Vol 73, 161-172; doi: 10.2495/DEB120141; $690 \quad$ ISSN 1743-3533.

691 Piegay H, Darby S, Mosselman E, Surian N. 2005. A review of techniques available for 692 delimiting the erodible river corridor: a sustainable approach to managing bank 693 erosion. River Research and Applications 21: 773-789.

694 Poff NL, Olden J D, Merritt DM, and Pepin DM. 2007. Homogenization of regional 695 river dynamics by dams and global biodiversity implications. Proceedings of the $696 \quad$ National Academy of Sciences 104: 5732-5737. 
697 Rigon E, Comiti F, Mao L, Lenzi MA. 2008. Relationships among basin area, sediment 698 transport mechanisms and wood storage in mountain basins of the Dolomites (Italian 699 Alps). WIT Transactions on Engineering Sciences 60: 163-172.

700 Rigon E, Comiti F, Lenzi MA. 2012. Large wood storage in streams of the Eastern 701 Italian Alps and the relevance of hillslope processes. Water Resource Research 48, 702 W01518, doi:10.1029/2010WR009854.

703 Rinaldi, M., Piégay, H., Surian, N., 2011. Geomorphological approaches for river 704 management and restoration in Italian and French rivers. in Stream Restoration in 705 Dynamic Fluvial Systems: Scientific Approaches, Analyses, and Tools, Geophys. 706 Monogr. Ser., vol. 194, edited by A. Simon, S. J. Bennett and J. M. Castro, pp. 95707 113, AGU, Washington, D. C., doi:10.1029/2010GM000984.

708 Surian N. 1999. Channel changes due to river regulation: the case of the Piave River, 709 Italy. Earth Surface Processes and Landforms 24: 1135-1151.

710 Surian N, Rinaldi M. 2003. Morphological response to river engineering and 711 management in alluvial channels in Italy. Geomorphology 50: 307-326.

712 Surian, N., Rinaldi, M., 2004. Channel adjustments in response to human alteration of 713 sediment fluxes: examples from Italian rivers. In: Golosov, V., Belyaev, V., Walling, 714 D.E. (Eds.), Sediment Transfer Through the Fluvial System, IAHS Publication N. 288. $715 \quad$, pp. 276-282.

716 Surian N, Cisotto A. 2007. Channel adjustments, bedload transport and sediment 717 sources in a gravel-bed river, Brenta River, Italy. Earth Surface Processes and $718 \quad$ Landforms 32: 1641-1656. 
719 Surian N, Mao L, Giacomin M, Ziliani L. 2009a. Morphological effects of different 720 channel-forming discharges in a gravel-bed river. Earth surface processes and 721 landforms 34: 1093-1107.

722 Surian N, Ziliani L, Comiti F, Lenzi, MA, Mao L. 2009b. Channel adjustments and 723 alteration of sediment fluxes in gravel-bed rivers of north-eastern Italy: Potentials and 724 limitations for channel recovery. River Research and Applications 25: 551-567.

725 Vitti P, Picco L, Mao L, Sitzia T, Comiti F, Rigon E, Lenzi MA. 2011. Linking riparian 726 forest structure and fluvio-morphological characteristics in a gravel bed river (Piave 727 river-Italian Alps). Poster presented at the International Workshop Advances in River 728 Science, 18-21 April 2011, Swansea, UK.

729 Ward JV, Tockner K, Edwards PJ, Kollmann J, Bretschko G, Gurnell AM, Petts GE, 730 Rossaro B. 1999. A reference river system for the alps: the Fiume Tagliamento. 731 Regulated rivers: Research \& Management 15: 63-75.

732

733

734

735

736

737

738

739

http://mc.manuscriptcentral.com/rra 
Tables

741

742 Table 1. Technical specifications of aerial image series used in the study. Px: pixel size;

743 Hf: height of flight; Fcl: focal, Q: Daily discharges $\left(\mathrm{m}^{3} \mathrm{~s}^{-1}\right)$.

744

\begin{tabular}{lrrrrrrc}
\hline Year & $\begin{array}{r}\text { Px } \\
(\mathrm{m})\end{array}$ & $\begin{array}{r}\text { Aprox. } \\
\text { Scale }\end{array}$ & $\begin{array}{r}\text { Hf } \\
(\mathrm{m})\end{array}$ & $\begin{array}{r}\text { Fcl } \\
(\mathrm{mm})\end{array}$ & Date flight & Company & $\begin{array}{c}\text { Q } \\
\left(\mathrm{m}^{3} \mathrm{~s}^{-1}\right)\end{array}$ \\
\hline 1981 & 1.00 & $1: 17000$ & 2600 & 153.13 & April 15 & CGR Parma & 38 \\
1990 & 1.00 & $1: 20000$ & 3000 & 152.82 & April 15 & CGR Parma & 31 \\
$1994^{*}$ & 0.35 & $1: 20000$ & 8000 & 305.38 & 20 Sept. & CGR Parma & 88 \\
1999 & 1.00 & $1: 16000$ & 2500 & 153.26 & July 23 & CGR Parma & 36 \\
2003 & 0.50 & $1: 10000$ & 5400 & 150.00 & May - Nov. & CGR Parma & 62 \\
2006 & 0.50 & $1: 10000$ & 5400 & 150.00 & May - Nov. & CGR Parma & 69 \\
2008 A & 0.40 & $1: 8000$ & 1250 & 153.64 & July 15 & Rossi - & 75 \\
2008 B & 0.75 & $1: 16000$ & 2400 & 153.64 & July & CGR Parma & 85 \\
2010 & 0.15 & $1: 12000$ & 2000 & 100.47 & August 30 & CGR Parma & 55 \\
2011 & 0.15 & $1: 12000$ & 2000 & $50-35$ & April 12 & OGS & 69 \\
\hline
\end{tabular}

745

*1994 flight does not include the upper part of the study reach.

746

747 Table 2. Temporal variation of the active channel (AC) width (m) and the talweg (Tw)

748 elevation (m a.s.l.) in the cross-sections (CS). It 'also shows the lateral ( $\triangle \mathrm{AC})$ and

749 vertical adjustments $(\Delta \mathrm{Tw})$.

750

\begin{tabular}{|c|c|c|c|c|c|c|c|c|c|c|}
\hline & \multicolumn{2}{|r|}{1923} & \multicolumn{2}{|r|}{1997} & \multicolumn{2}{|r|}{2010} & \multicolumn{2}{|c|}{$1997-1923$} & \multicolumn{2}{|c|}{$2010-1997$} \\
\hline & $\begin{array}{l}\text { AC } \\
(\mathrm{m})\end{array}$ & $\begin{array}{l}\text { Tw } \\
\text { (m a.s.l.) }\end{array}$ & $\begin{array}{r}\mathrm{AC} \\
(\mathrm{m})\end{array}$ & $\begin{array}{l}\mathrm{Tw} \\
\text { (m a.s.1.) }\end{array}$ & $\begin{array}{r}\mathrm{AC} \\
(\mathrm{m})\end{array}$ & $\begin{array}{l}\mathrm{Tw} \\
\text { (m a.s.1.) }\end{array}$ & $\begin{array}{c}\Delta \mathrm{AC} \\
(\mathrm{m})\end{array}$ & $\begin{array}{c}\Delta \mathrm{Tw} \\
(\mathrm{m})\end{array}$ & $\begin{array}{c}\Delta \mathrm{AC} \\
(\mathrm{m})\end{array}$ & $\begin{array}{c}\Delta \mathrm{Tw} \\
(\mathrm{m})\end{array}$ \\
\hline CS 1 & 248 & 91.6 & 87 & 92.2 & 90 & 90.4 & -161 & 0.6 & 3 & -1.8 \\
\hline CS 2 & 401 & 85.1 & 158 & 83.9 & 230 & 82.6 & -243 & -1.2 & 72 & -1.3 \\
\hline CS 3 & 838 & 75.1 & 427 & 73.3 & 572 & 72.6 & -411 & -1.8 & 145 & -0.7 \\
\hline CS 4 & 699 & 67.6 & 413 & 63.8 & 506 & 63.4 & -286 & -3.8 & 93 & -0.4 \\
\hline CS 5 & 409 & 59.8 & 263 & 56.0 & 310 & 55.0 & -146 & -3.8 & 47 & -1.0 \\
\hline CS 6 & 541 & 54.6 & 514 & 50.0 & 520 & 49.1 & -27 & -4.6 & 6 & -0.9 \\
\hline CS 7 & 752 & 43.9 & 479 & 37.6 & 480 & 38.3 & -273 & -6.3 & 1 & 0.7 \\
\hline CS 8 & 303 & 37.9 & 258 & 33.6 & 242 & 33.4 & -45 & -4.3 & -16 & -0.2 \\
\hline CS 9 & 744 & 34.7 & 482 & 24.6 & 477 & 24.8 & -262 & -10.1 & -5 & 0.2 \\
\hline CS 10 & 409 & 29.9 & 359 & 22.1 & 361 & 22.1 & -50 & -7.8 & 2 & 0.0 \\
\hline
\end{tabular}


752 FIGURE CAPTIONS

753 Figure 1. General view of the Brenta River context, the study reach and the cross-

754 sections.

755

756 Figure 2. Water discharges (mean daily) at the Barzizza gauging station (Bassano Del

757 Grappa, drainage area $=1567 \mathrm{~km}^{2}$ ), from 1924 until June 2011; Flow discharges

758 featuring $\mathrm{RI}=1.5$ years $\left(\mathrm{Q}_{1.5}\right)$, and $\mathrm{RI}=10$ years $\left(\mathrm{Q}_{10}\right)$ are also shown.

759

760 Figure 3. (a) Longitudinal profiles of the Brenta river from 1932 and 1997 survey 761 (Surian and Cisotto, 2007) and 2010. Best equations (exponentials) of the longitudinal 762 profiles are reported (the all three profiles $r^{2}>0.95$ ); (b) variation of average bed 763 elevation as derived from the comparison of cross-sections along the study reach from 764 section 1 to 10 are shown: negative values of vertical adjustments indicate an incision of 765 streambed whereas positive values indicate an aggradation. 2011 sections are derived 766 from LiDAR survey (Moretto et al., 2012) and are available only for sections 2, 5, and 7677.

768

769 Figure 4. Evolution of historical cross sections 2, 5, and 7 for the years 1932, 1997, 770 2010, and 2011. The horizontal line represents the bankfull stage for the sections 771 measured in 2010.

772

773 Figure 5. Temporal variation with error bars of the surface of the active channel, 774 floodplain and islands in the analyzed reach of the Brenta River. 
776 Figure 6. Active channel evolution over the last 30 years divided in five significant 777 periods characterized by different morphological trends.

778

779 Figure 7. Fluvial Island evolution over the last 30 years divided in five significant 780 periods characterized by different morphological trends of active channel.

782 Figure 8. Relationship between the changes of elevation of the bankfull stage and 783 changes of active channel width evaluated in 10 historical cross-sections. The two 784 reported series refer to the periods 1932-1997, and 1997-2010. Negative values mean 785 narrowing or incision, while positive values correspond to widening or aggradation.

Figure 9. Time evolution of the average active channel width and RI of flood events. (a) Bar chart represents the maximum hourly discharge registered in the year $(\mathrm{Qh})$ and the maximum annual values of the mean daily water discharge $(\mathrm{Q})$; dashed line $\left(\mathrm{Qh}_{\text {mean }}\right)$ represents the average of the annual Qh over a period between two aerial photointerpretation. Flow discharges featuring $R I=1.5$ years $\left(Q_{1.5}\right)$, and $R I=10$ years $\left(Q_{10}\right)$

792 are also shown. (b) Adjustments of the average active channel width (whole reach and sub-reaches). Maximum annual peak discharges value was not available at the Barzizza 794 gauging station for the year 1985.

Figure 10. Rate of active channel width variation $\left(\mathrm{m} \mathrm{year}^{-1}\right)$ in relation of the average of 797 annual daily peak discharge (Qh $\left.\mathrm{m}^{3} \mathrm{~s}^{-1}\right)$ over photo periods and the corrispondent $\mathrm{RI}$. 


1
2
3
4
5
6
7
8
9
10
11
12
13
14
15
16
17
18
19
20
21
22
23
24
25
26
27
28
29
30
31
32
33
34
35
36
37
38
39
40
41
42
43
40
45
49
50
50
51
53
55
50

799 Figure 11. Lateral adjustment rate versus the number of the days per year with Qd over $800450 \mathrm{~m}^{3} \mathrm{~s}^{-1}$ for the photo period. 


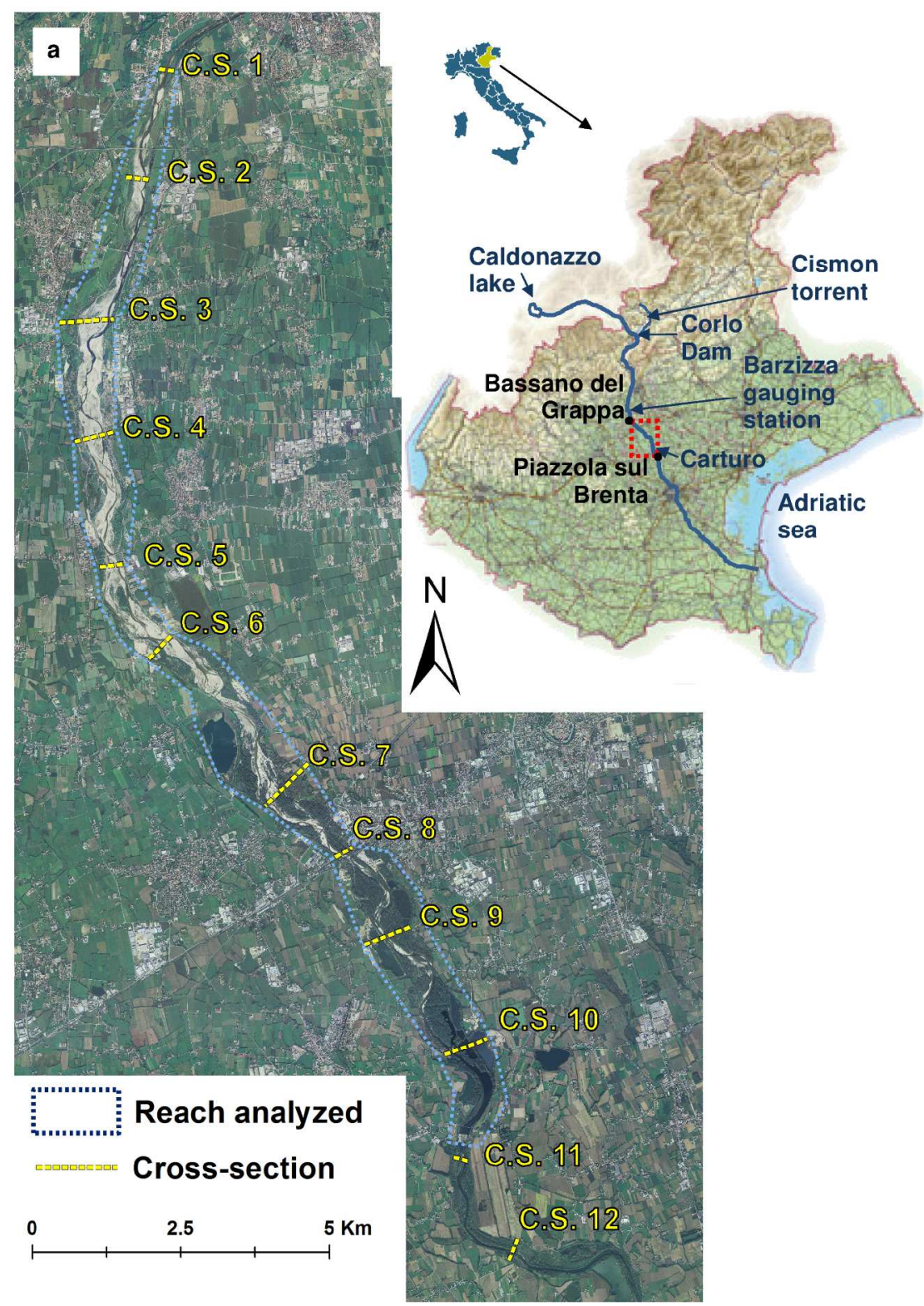

Figure 1. General view of the Brenta river context, the study reach and the cross-sections. $230 \times 324 \mathrm{~mm}(300 \times 300 \mathrm{DPI})$ 
Figure 2. Water discharges (mean daily) at the Barzizza gauging station (Bassano del Grappa, drainage area $=1567 \mathrm{~km}^{2}$ ), from 1924 until June 2011; Flow discharges featuring $\mathrm{RI}=1.5$ years $\left(\mathrm{Q}_{1.5}\right)$, and $\mathrm{RI}=10$ years $\left(Q_{10}\right)$ are also shown. $61 \times 20 \mathrm{~mm}(300 \times 300 \mathrm{DPI})$ 

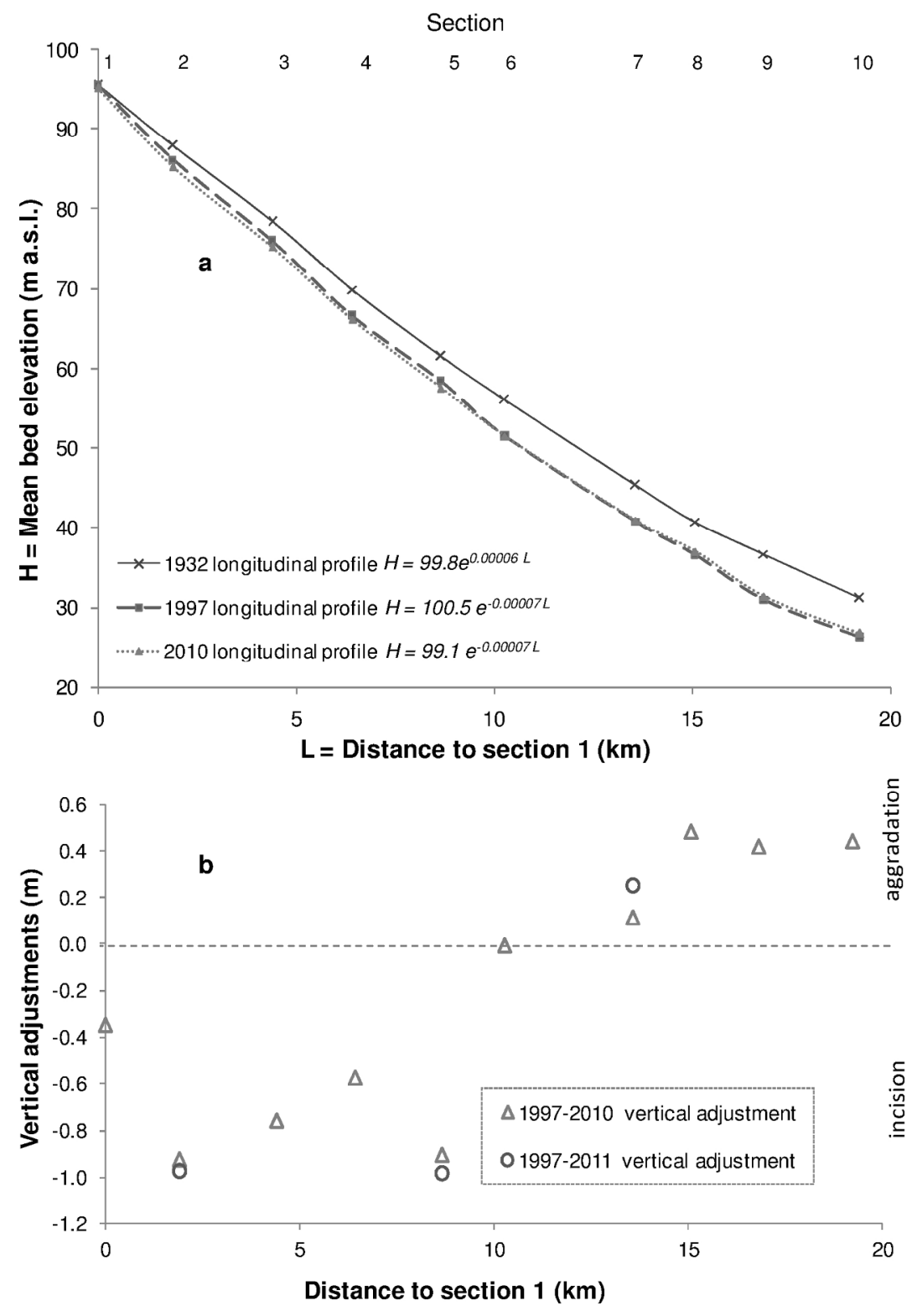

Figure 3. (a) Longitudinal profiles of the Brenta river from 1932 and 1997 survey (Surian and Cisotto, 2007) and 2010. Best equations (exponentials) of the longitudinal profiles are reported (the all three profiles $\left.r^{2}>0.95\right)$; (b) variation of average bed elevation as derived from the comparison of cross-sections along the study reach from section 1 to 10 are shown: negative values of vertical adjustments indicate an incision of streambed whereas positive values indicate an aggradation. 2011 sections are derived from LiDAR survey (Moretto et al., 2012) and are available only for sections 2, 5, and 7. $151 \times 216 \mathrm{~mm}(300 \times 300 \mathrm{DPI})$ 

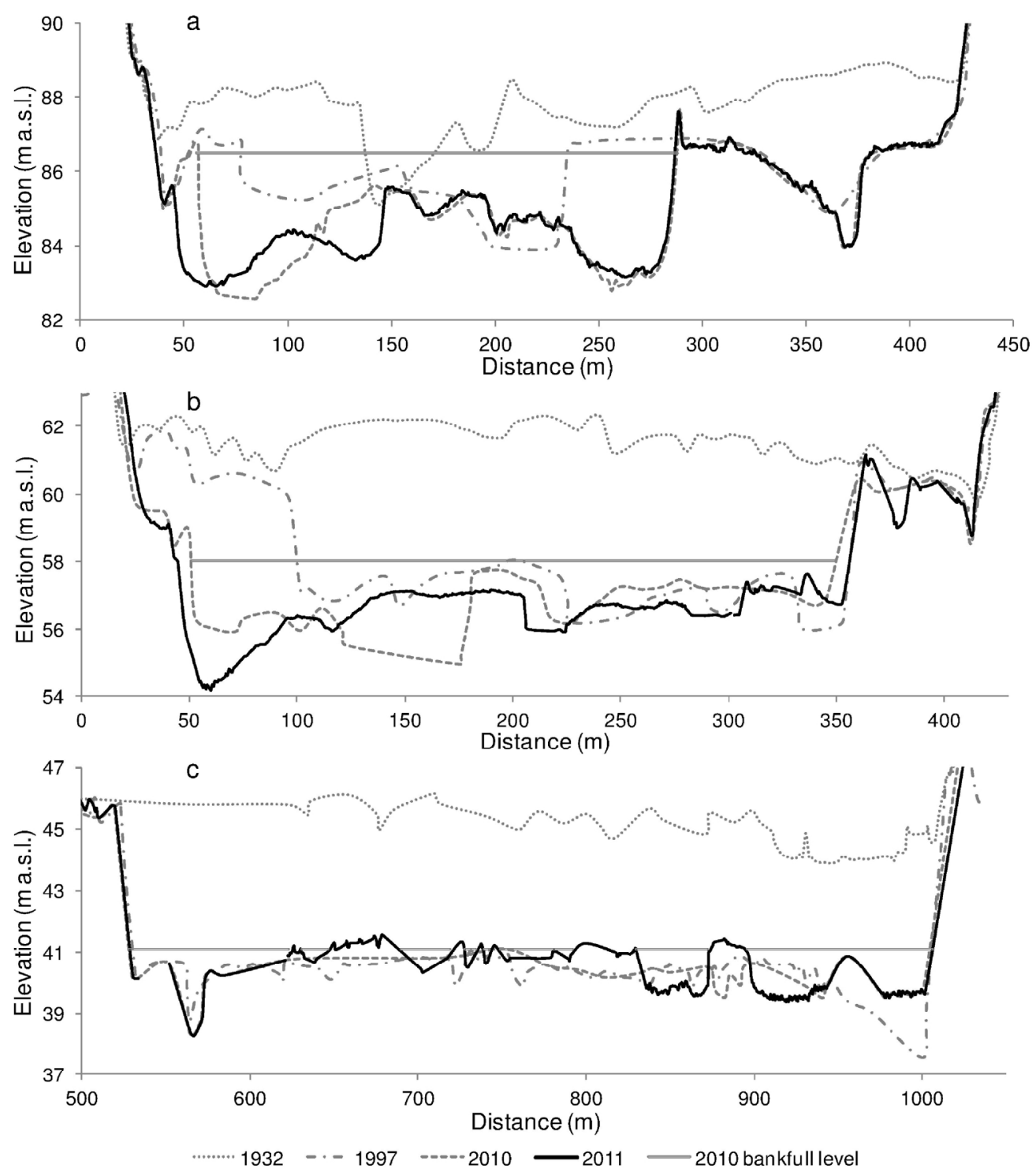

Figure 4. Evolution of historical cross sections 2, 5, and 7 for the years 1932, 1997, 2010, and 2011. The horizontal line represents the bankfull stage for the sections measured in 2010 . $193 \times 223 \mathrm{~mm}(300 \times 300$ DPI $)$ 


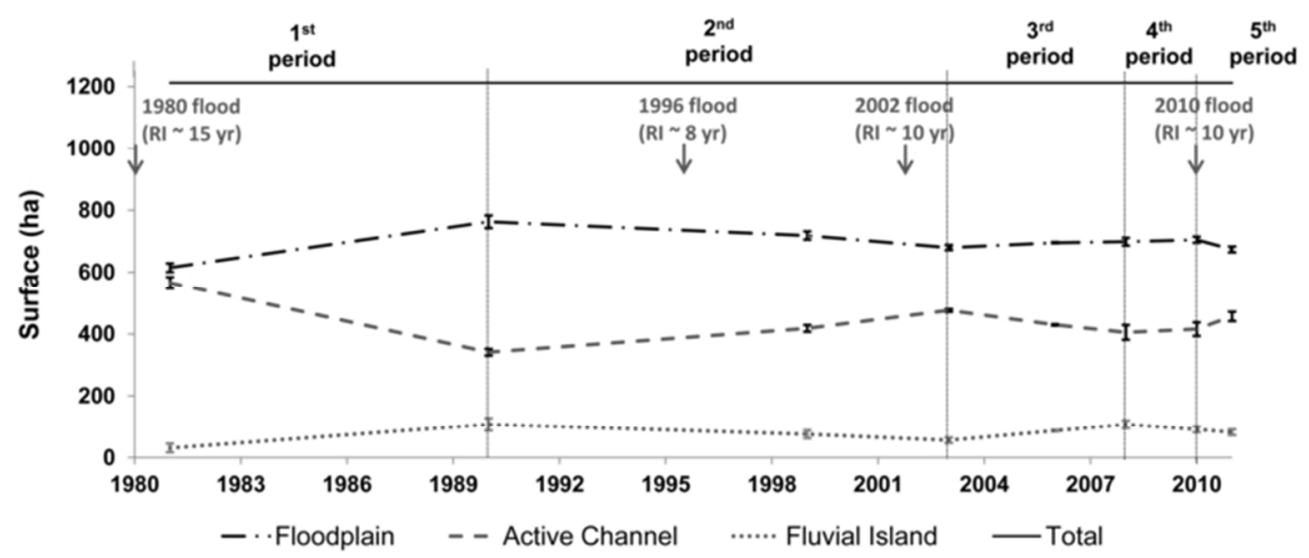

Figure 5. Temporal variation with error bars of the surface of the active channel, floodplain and islands in the analyzed reach of Brenta River. $62 \times 26 \mathrm{~mm}(300 \times 300 \mathrm{DPI})$ 


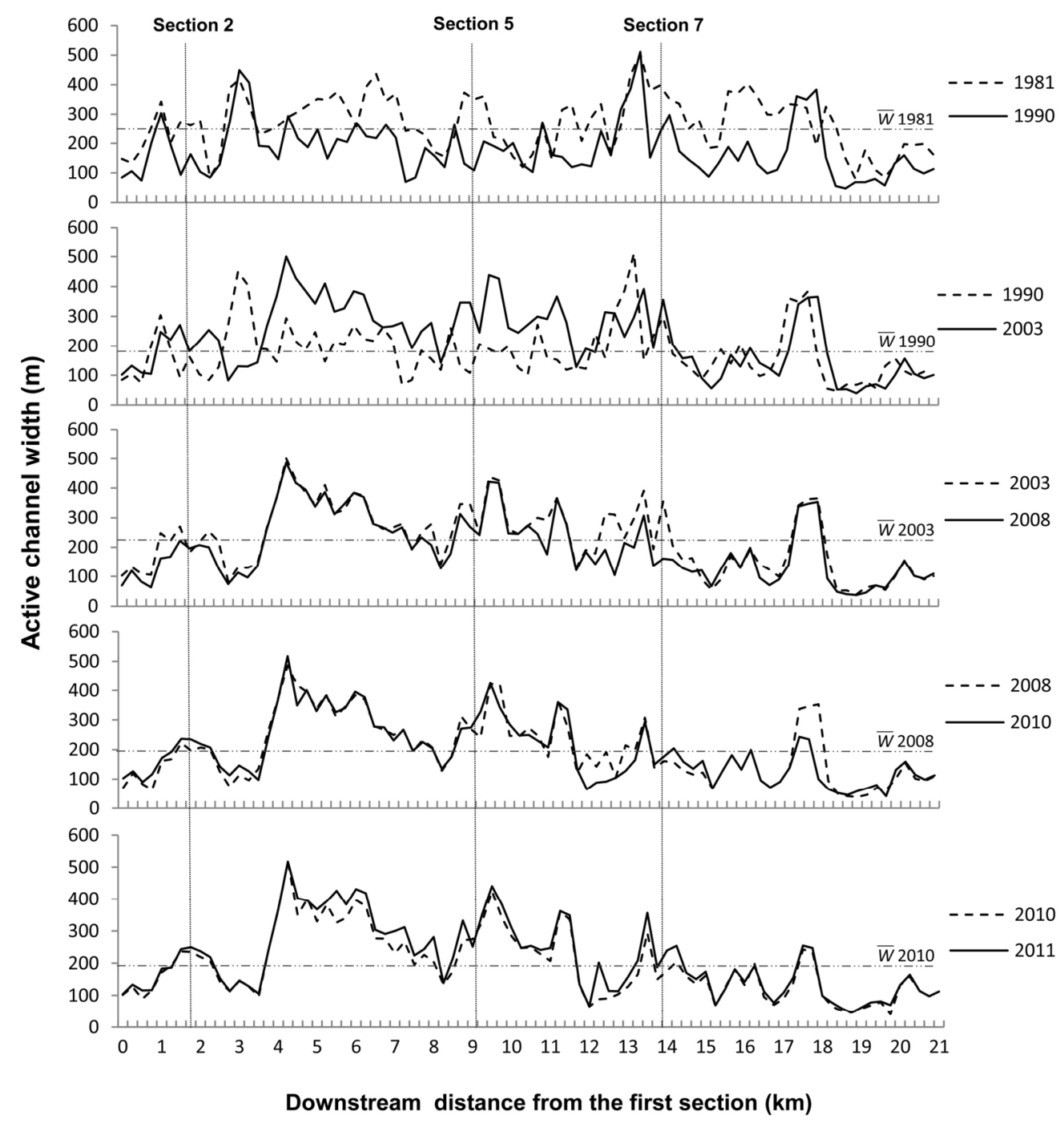

Figure 6. Active channel evolution over the last 30 years divided in five significant periods characterized by different morphological trends. $171 \times 182 \mathrm{~mm}(300 \times 300 \mathrm{DPI})$ 


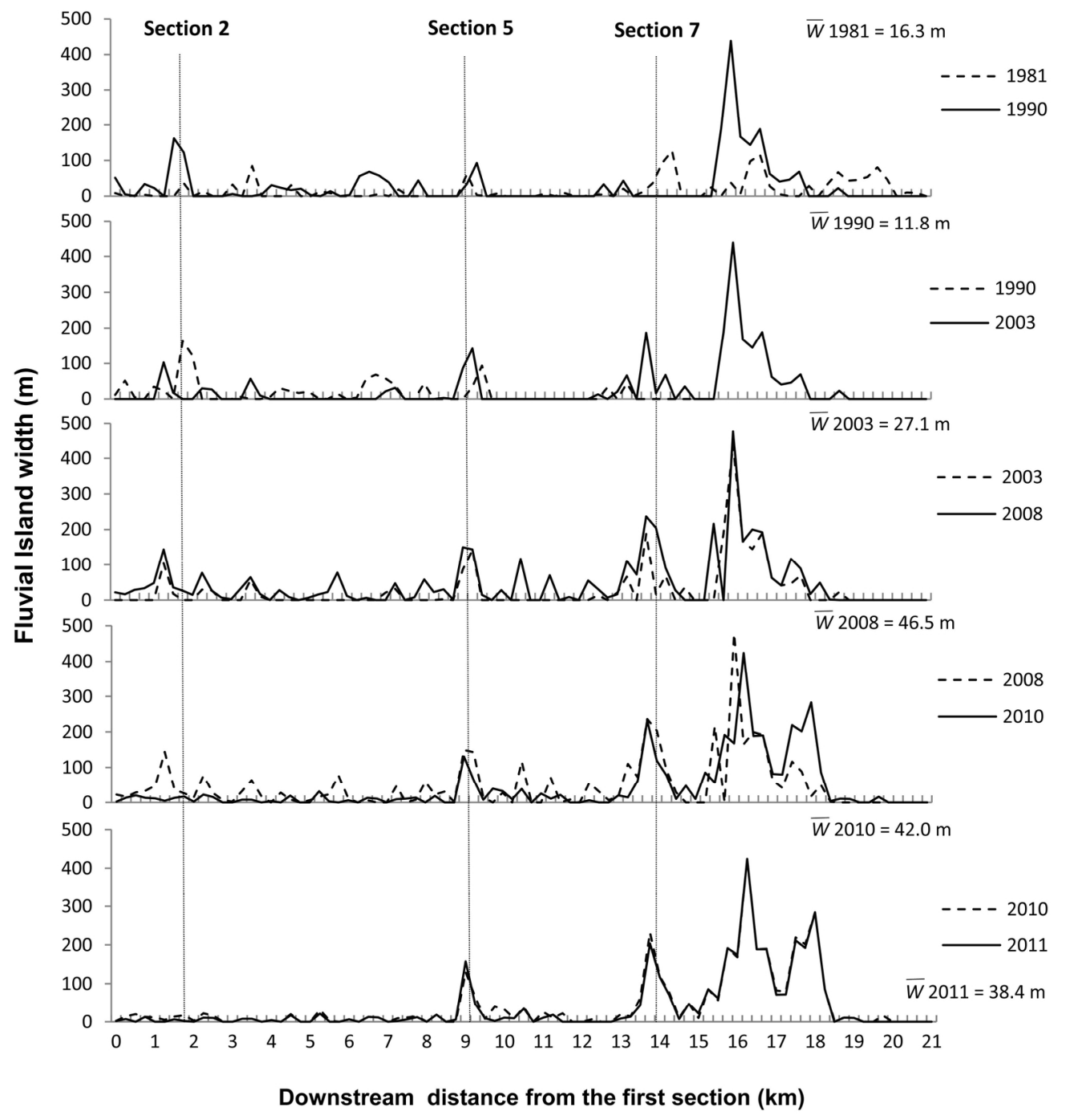

Figure 7. Fluvial island evolution over the last 30 years divided in five significant periods characterized by different morphological trends of active channel. $171 \times 181 \mathrm{~mm}(300 \times 300 \mathrm{DPI})$ 
Figure 8. Relationship between the changes of elevation of the bankfull stage and changes of active channel width evaluated at 10 historical cross-sections. The two reported series refer to the periods 1932-1997, and 1997-2010. Negative values mean narrowing or incision, while positive values correspond to widening or aggradation.

$105 \times 66 \mathrm{~mm}(300 \times 300 \mathrm{DPI})$ 


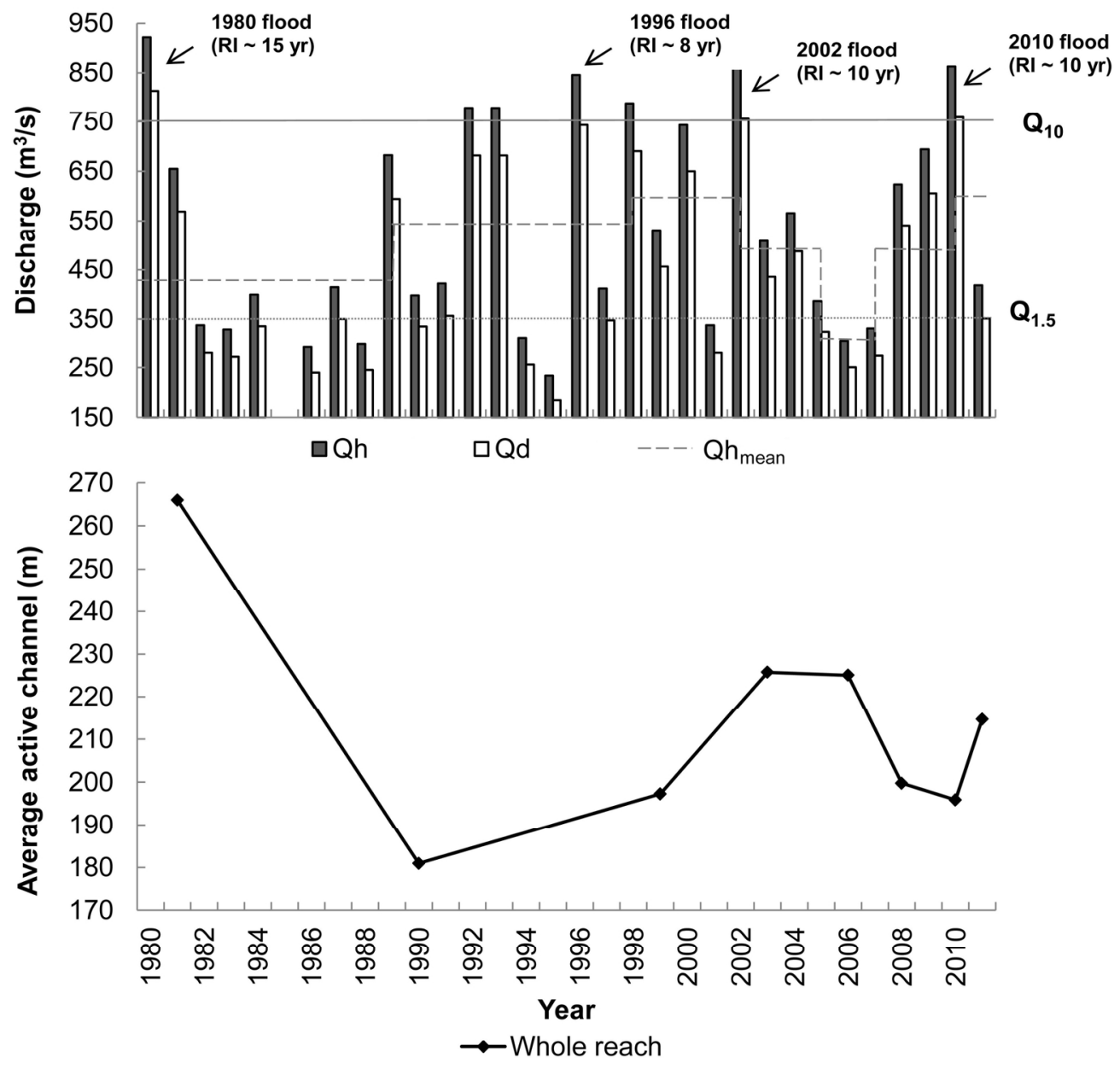

Figure 9. Time evolution of the average active channel width and RI of flood events. (a) Bar chart represents the maximum hourly discharge registered in the year (Qh) and the maximum annual values of the mean daily water discharge $(\mathrm{Q})$; dashed line $\left(\mathrm{Qh}_{\text {mean }}\right)$ represents the average of the annual Qh over a period between two aerial photo-interpretation. Flow discharges featuring $\mathrm{RI}=1.5$ years $\left(\mathrm{Q}_{1.5}\right)$, and $\mathrm{RI}=10$ years $\left(Q_{10}\right)$ are also shown. (b) Adjustments of the average active channel width (whole reach and subreaches). Maximum annual peak discharges value was not available at the Barzizza gauging station for the year 1985.

$162 \times 156 \mathrm{~mm}(300 \times 300 \mathrm{DPI})$ 
Figure 10. Rate of active channel width variation $\left(\mathrm{m} \mathrm{year}^{-1}\right)$ in relation to the average of annual daily peak discharge (Qd $\left.\mathrm{m}^{3} \mathrm{~s}^{-1}\right)$ over photo periods and the correspondent recurrence interval. $725 \times 412 \mathrm{~mm}(120 \times 120 \mathrm{DPI})$ 


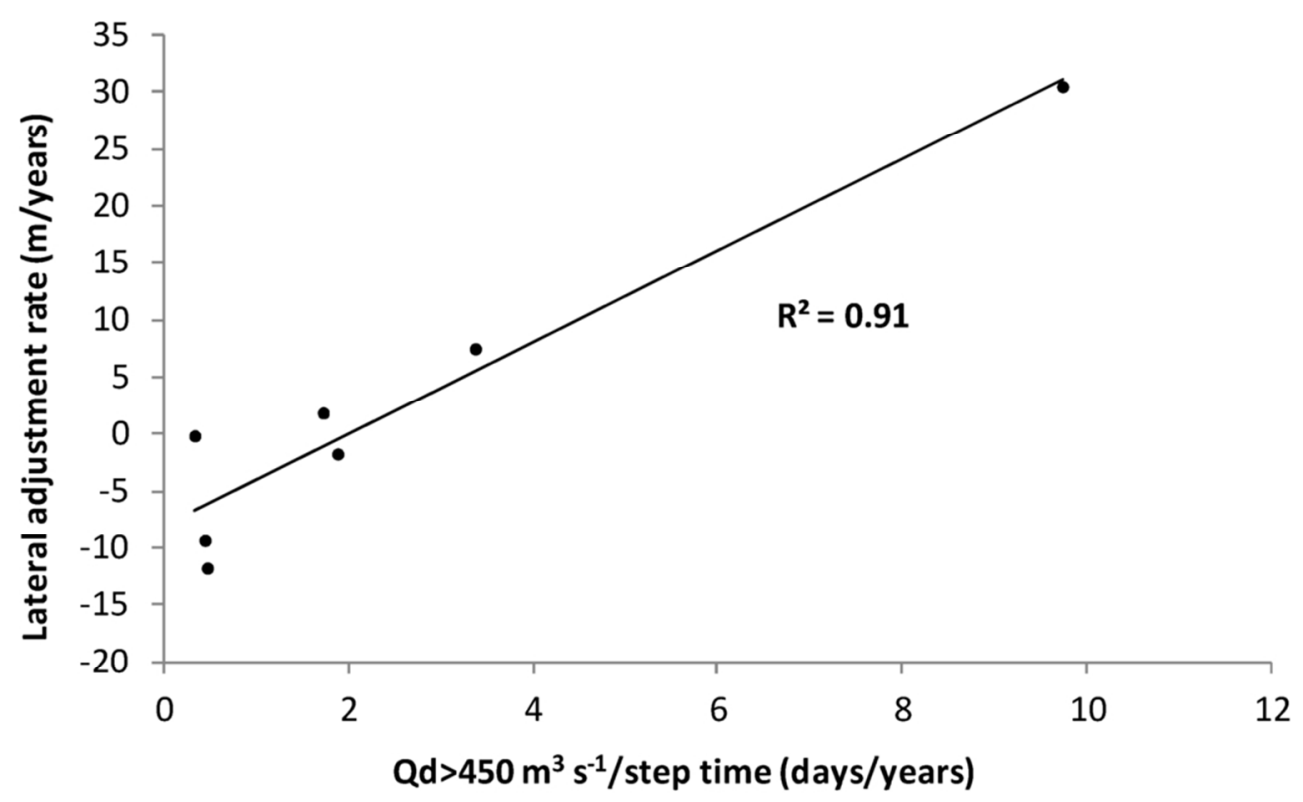

Figure 11. Lateral adjustment rate versus the number of the days per year with Qd over $450 \mathrm{~m}^{3} \mathrm{~s}^{-1}$ for the photo period.

$90 \times 55 \mathrm{~mm}(300 \times 300$ DPI $)$ 